\title{
A Tailored AlSiMg Alloy for Laser Powder Bed Fusion
}

\author{
Daniel Knoop ${ }^{1,2, *}$, Andreas Lutz ${ }^{3}$, Bernhard Mais ${ }^{4}$ and Axel von Hehl 1,2,5 \\ 1 Leibniz-Institute for Materials Engineering, 28359 Bremen, Germany; vonhehl@iwt-bremen.de \\ 2 University of Bremen, 28359 Bremen, Germany \\ 3 Mercedes-Benz AG, 70372 Stuttgart, Germany; andreas.an.lutz@daimler.com \\ 4 Ecka Granules Germany GmbH, 91235 Velden, Germany; Bernhard.Mais@kymerainternational.com \\ 5 Tandon School of Engineering, New York University, Brooklyn, NY 11201, USA \\ * Correspondence: dknoop@iwt-bremen.de; Tel.: +49-421-218-51435
}

Received: 19 March 2020; Accepted: 13 April 2020; Published: 16 April 2020

\begin{abstract}
The majority of aluminum alloys used for laser powder bed fusion are based on the aluminum-silicon system, particularly alloys containing 7 to $12 \mathrm{wt} . \%$ silicon and less than $1 \mathrm{wt} . \%$ magnesium. Silicon has a beneficial influence on melt viscosity during casting and laser additive manufacturing and prevents the formation of cracks. This study focused on the development of a new AlSi3.5Mg2.5 alloy for laser powder bed fusion with a Mg-Si content above $1.85 \mathrm{wt} . \% \mathrm{Mg}_{2} \mathrm{Si}$, which is the solubility limit of the $\alpha$-aluminum matrix, and a subsequent heat treatment to adjust the mechanical properties with a wide range of strength and ductility values. The characterization of the microstructure was conducted by optical microscopy, scanning electron microscopy, transmission electron microscopy, and differential scanning calorimetry. The mechanical properties were determined by tensile tests and additional tight radius bending tests. The newly developed alloy was compared with AlSi10Mg and Scalmalloy ${ }^{\circledR}$. AlSi3.5Mg2.5 offers higher strength and ductility than AlSi10Mg, at comparable material costs. The mechanical properties can be adjusted in a wide range of values using a single step heat treatment. After direct ageing, the samples exhibited a ultimate tensile strength (UTS) of $484 \pm 1 \mathrm{MPa}$ and an elongation at break of $10.5 \% \pm 1.3 \%$, while after soft annealing, they exhibited a UTS of $179 \pm 2 \mathrm{MPa}$ and an elongation at break of $25.6 \% \pm 0.9 \%$.
\end{abstract}

Keywords: selective laser melting; laser additive manufacturing; laser powder bed fusion; aluminum; heat treatment; AlSiMg; scalmalloy; mechanical properties; age hardening; AlSi10Mg

\section{Introduction}

The frequent use of the alloy AlSi10Mg in laser powder bed fusion (LPBF), also called selective laser melting, is due to the high technological maturity of its application compared to other aluminum alloys and its favorable solidification behavior. In comparison with conventional wrought alloys, hypoeutectic casting alloys have a poorer strength to ductility ratio. An AlSi10Mg alloy in as-built condition without heat treatment will achieve a tensile strength of about $400 \mathrm{MPa}$ and a yield strength of about $300 \mathrm{MPa}$ at a low elongation at break of about $5 \%$ [1-3]. These values are significantly above the characteristic values achieved by casting [4] and are the consequence of a completely different microstructure due to rapid solidification during additive manufacturing.

The high strength of the alloy in as-built condition is determined by the structure of its supersaturated $\alpha$-aluminum matrix and fine network of eutectic Si. Stress-relief annealing at $300^{\circ} \mathrm{C}$ results in a decrease in strength and an increase in elongation at break. Heat treatment steps, such as solution annealing and artificial ageing, are not common, as they lead to a significant reduction in strength compared to the as-built condition. At higher temperatures, the silicon precipitates from the supersaturated matrix into spherical particles, and the silicon network dissolves as the Si particles 
coarsen [1,2]. Currently, there are only a few alternative processable aluminum alloys for additive manufacturing. These include casting alloys like AlSiCu alloys (EN AC-46xxx and EN AC-47xxx). These alloys offer high tensile strengths of up to $500 \mathrm{MPa}$ with a low elongation at break of 5\% [5-7].

Many known alloys are difficult to process by laser powder bed fusion due to the formation of pores and cracks during solidification. These include medium and high strength wrought alloys of the alloy systems AlCu (EN AW-2xxx) [8-10], AlMgSi (EN AW-6xxx) [11,12], and AlZnMg (EN AW-7xxx) [13-15]. Known structural concepts for the development of alloys that are adapted to the additive manufacturing process use rare earth elements, such as scandium and zirconium, with varying content [16-18] or feature the addition of nanoscale grain refining additives to the known wrought alloys, such as the alloy EN AW-7075 [19]. When processed by laser additive manufacturing, both approaches lead to a combination with a high strength above $500 \mathrm{MPa}$ combined with a good elongation at break of up to $15 \%$. The disadvantages of these approaches are the high costs of scandium and the application of nanoparticles. A more detailed review of investigations into aluminum alloys for the LPBF process can be found in [20,21].

The use of EN AW-6xxx alloys, whose strength is based on precipitation hardening, promises medium strength with a smaller decrease in ductility at low material costs. Artificial ageing leads to the formation of magnesium/silicon precipitates, which hinder dislocation movement [22]. Alloys of the EN AW-6xxx class are considered poorly weldable due to their tendency to forms cracks without the use of silicon containing filler materials that change the local chemical composition in the weld [23]. Without an appropriate filler material, cracking is caused by the low Si content of the alloys, which can also occur during laser powder bed fusion. In preliminary tests, crack-free samples could not be produced with an alloy with a Si-content of $1.5 \mathrm{wt} . \%$.

Especially in the automotive industry, there is a need for a low-cost, flexible alloy system, which, depending on the heat treatment used, can represent a high-strength range of properties, as well as a state of increased ductility. The alloy system EN AW-6xxx, based on the cost-effective main alloying elements silicon and magnesium, is a suitable solution for this purpose.

In this paper, a new optimized aluminum alloy for laser powder bed fusion is presented and characterized. This approach involves reducing the silicon content of the alloy compared to the widely used alloy AlSi10Mg and increasing the magnesium content compared to EN AW-6xxx alloys. The silicon content was $3.5 \mathrm{wt} . \%$, which is just above the limit considered uncritical for crack tendency [24]. This compositional change was expected to result in less embrittlement of the material but also in a reduction in strength. This strength decrease was compensated by increasing the magnesium content to $2.5 \mathrm{wt} . \%$, which caused a stronger precipitation-controlled hardening reaction and more intense strengthening of the solid solution.

The slow cooling of the conventional casting processes leads to the formation of coarse primary precipitates, which then have to be dissolved by solution annealing in order to gain a supersaturated solution by quenching from the solution annealing temperature to room temperature. This is followed by controlled artificial ageing at temperatures between 150 to $190^{\circ} \mathrm{C}$ for several hours, when fine secondary precipitates form and increase the strength of the material. In contrast, due to the process-inherent rapid quenching from the melt under laser powder bed fusion (LPBF), no coarse primary precipitates could be formed. Furthermore, the $\mathrm{Mg}_{2} \mathrm{Si}$ content exceeding the maximum solubility of $1.85 \mathrm{wt} . \%$ of $\mathrm{Mg}_{2} \mathrm{Si}$ in the solid state could be dissolved and introduced into the supersaturated solution. Maximum solubility limits the strength of the EN AW-6xxx alloys. These modifications also allowed us to significantly extend the range within which the mechanical properties could be adjusted.

\section{Materials and Methods}

To validate the presented concept, an alloy of the composition AlSi3.5Mg2.5 with additions of common micro alloying elements was processed by gas atomization into a powder with a particle size distribution between 20 and $63 \mu \mathrm{m}$. The chemical composition corresponds to a theoretical maximum $\mathrm{Mg}_{2} \mathrm{Si}$ content of $3.96 \mathrm{wt} . \%$. This was followed by the development of suitable 
process parameters for the LPBF-process and subsequent heat treatment, as well as mechanical and microstructural characterization.

\subsection{Gas Atomization and Powder Characterization}

The powder was produced by Ecka Granules Germany GmbH (Velden, Germany) via closed-coupled gas atomization, a commonly used process for metal powder production. The chemical composition was measured by inductively coupled plasma optical emission spectroscopy (ICP-OES). The oxygen and hydrogen content was measured by the inert gas fusion method. To complete the characterization of the powder, the particle size distribution was measured by laser diffraction spectrometry, and the shape of the particles was checked by using scanning electron microscopy (SEM) images.

\subsection{Laser Powder Bed Pusion}

The successful use of an alloy in the laser powder bed fusion process presupposes the possibility of producing dense and crack-free parts. The essential process parameters to control the energy input into the powder bed are the laser power $P_{L}$, the scanning speed $V_{S}$, the layer thickness $d_{S}$, and the hatch distance $h_{S}$, which represents the distance between two adjacent scan vectors. To narrow the parameter field, experiments were carried out on a laser additive manufacturing system SLM Solutions SLM $125 \mathrm{HL}$. The system was built with a volume of $125 \times 125 \times 150 \mathrm{~mm}^{3}$ and a Yb-fibre laser with a wavelength of $1070 \mathrm{~nm}$ and a maximum laser power of $400 \mathrm{~W}$. The minimum focus diameter was $68 \mu \mathrm{m}$. The best results were obtained with a volume energy density of $61.7 \mathrm{~J} / \mathrm{mm}^{3}$, a laser power of $370 \mathrm{~W}$ and a layer thickness of $50 \mu \mathrm{m}$.

This parameter set was used for the production of all AlSi3.5Mg2.5 samples that were manufactured with the SLM 125 LPBF-system and analyzed within this paper. At a later stage of investigation, parameter transfer to an additive manufacturing system Concept Laser M2 was carried out. This M2 LPBF-system provided a larger build envelope to enable the manufacturing of larger parts. In order to compare the developed alloys with common aluminum-LPBF alloys, samples of AlSi10Mg and the AlMgSc alloy Scalmalloly ${ }^{\circledR}$ were printed. The AlSi10Mg samples were manufactured on an LPBF-system Concept Laser M2 (GE Additive, Munich, Germany) with a layer thickness of $30 \mu \mathrm{m}$ and a volume energy density of $82.2 \mathrm{~J} / \mathrm{mm}^{3}$. The Scalmalloy ${ }^{\circledR}$-samples (Munich, Germany) were manufactured on an LPBF-system EOS M290 (Krailling, Germany) with a layer thickness of $45 \mu \mathrm{m}$ and an energy density of $48 \mathrm{~J} / \mathrm{mm}^{3}$.

\subsection{Microstructure}

The microstructure under the as-built conditions after additive manufacturing was examined by optical microscopy (OM), electron backscatter diffraction (EBSD), and transmission electron microscopy (TEM). For the OM analysis, the sample was ground and polished longitudinally to the build-up direction and etched for $40 \mathrm{~s}$ with an aqueous solution containing 10 vol.\% sulfuric acid and 5 vol. $\%$ hydrofluoric acid. The grain orientation and grain size were measured using EBSD with a Philips REM XL 30 (Amsterdam, The Netherlands) on the specimens transversely and longitudinally oriented to the build-up direction with an accelerating voltage of $25 \mathrm{kV}$ and a $0.5 \mu \mathrm{m}$ increment of the measuring points. Further microstructure investigations were carried out with a transmission electron microscope FEI Titan 80-300 (National Institute of Standards and Technology, Gaithersburg, MD, USA) at an acceleration voltage of $300 \mathrm{kV}$. This instrument was equipped with an energy-dispersive $X$-ray spectroscopy (EDS) detector for element analysis. The sample preparation for the TEM analysis was carried out using a focused ion beam.

\subsection{Heat Treatment and Mechanical Testing}

To develop an optimized heat treatment process for parts manufactured by laser powder bed fusion, variations time and temperature were varied to investigate a suitable heat treatment process to 
achieve two different mechanical profiles (for strength dominated and ductility dominated use cases). To achieve a mechanical property profile with a higher strength, the samples were directly artificially aged (i.e., direct ageing) at temperatures between $140{ }^{\circ} \mathrm{C}$ and $190{ }^{\circ} \mathrm{C}$ for $15 \mathrm{~min}$ up to $8 \mathrm{~h}$ without prior annealing. To establish more ductile material behavior in AlSi based alloys, the heat treatment consisted of soft annealing at elevated temperatures above the ageing temperatures. These experiments were performed by annealing the samples in their as-built state at temperatures between $250{ }^{\circ} \mathrm{C}$ and $380^{\circ} \mathrm{C}$ for $15 \mathrm{~min}$ up to $1 \mathrm{~h}$. All samples were cooled in ambient air.

To evaluate the effect of the different heat treatment parameters, vertical (oriented along the build-up direction) rod-shaped cylindrical samples were constructed for tensile tests. The tensile tests were performed according to DIN EN ISO 6892-1. Specimens with a test diameter of $5 \mathrm{~mm}$ according to DIN 50125 type B were machined. For advanced characterization of the ductility of the tight radius, bending tests were performed according to VDA 238-100. The bending samples with dimensions of $30 \mathrm{~mm} \times 60 \mathrm{~mm} \times 2 \mathrm{~mm}$ were tested without further surface machining. The tip radius of the fin was $0.2 \mathrm{~mm}$, and a traverse speed of $20 \mathrm{~mm} / \mathrm{min}$ was applied. Furthermore, AlSi10Mg was tested in its as-built condition and after a soft annealing treatment analogous to AlSi3.5Mg2.5 to increase ductility. Scalmalloy ${ }^{\circledR}$ was tested in its as-built condition and after direct ageing at $325{ }^{\circ} \mathrm{C}$ for $4 \mathrm{~h}$-a widely used type of heat treatment that provides a strong ageing response $[25,26]$. For all three alloys, tensile tests were performed to determine the strength. The accompanying tensile tests were also carried out without machining the specimen surfaces. A minimum amount of three samples for each heat treatment parameter set was investigated.

As the examined alloy is age-hardenable, the influence of the process temperature on the precipitation behavior during the manufacturing process, which has not been considered in research so far, was investigated. To reduce the residual stresses, the substrate plate is commonly heated up to $200{ }^{\circ} \mathrm{C}$ during the laser powder bed fusion process. At this temperature, precipitation hardening usually occurs during construction. Due to its printing time of several hours, a temperature of $200{ }^{\circ} \mathrm{C}$ leads to over-ageing of the alloy.

Therefore, the samples were built up using platform temperatures of $50{ }^{\circ} \mathrm{C}$ and $120^{\circ} \mathrm{C}$ and examined in their as-built states by means of tensile testing and differential scanning calorimetry (DSC) to verify this presumption. For the DSC measurement, cylindrical specimens with a diameter of $4 \mathrm{~mm}$ and a height of $1 \mathrm{~mm}$ were cut from additional blanks for the tensile test by electrical discharge machining. This measurement was performed with a dynamic differential calorimeter DSC3+ from Mettler Toledo $\mathrm{GmbH}$ (Giessen, Germany) with a heating rate of $10 \mathrm{~K} / \mathrm{min}$. The development of the heat treatment was carried out with samples that were built up with a platform temperature of $50{ }^{\circ} \mathrm{C}$, as these samples provide the maximum potential for artificial direct ageing. A limitation of the platform temperature to $50^{\circ} \mathrm{C}$ with the SLM 125 LPBF-system (SLM SOLUTIONS GROUP AG, Lubeck, Germany) was achieved by pausing this process for $3 \mathrm{~min}$ after the exposure of each layer.

\section{Results and Discussion}

\subsection{Powder Characterization}

Table 1 shows the chemical composition of the powder, which deviated only slightly from the nominal composition of AlSi3.5Mg2.5.

Table 1. The chemical composition of the powder and bulk material after additive manufacturing ${ }^{1}$.

\begin{tabular}{ccccccc}
\hline Elements & $\mathbf{S i}$ & $\mathbf{M g}$ & $\mathbf{O}$ & $\mathbf{H}$ & Other $^{2}$ & $\mathbf{A l}$ \\
\hline Powder & 3.3 & 2.3 & 0.07 & $97 \mathrm{ppm}$ & 0.43 & Bal. \\
\hline \multicolumn{7}{c}{ Data in wt.\% unless otherwise stated. ${ }^{2}$ Including $\mathrm{Mn}, \mathrm{Zr}, \mathrm{Fe}$, and other impurities. }
\end{tabular}


The measured particle size distribution was within the specified size range. Figure 1a shows the density function q3 and the cumulative particle size distribution Q3. The lower classification cut-off is in good agreement with the specifications. At the upper end, there were some particles that exceeded the diameter of $63 \mu \mathrm{m}$. The SEM image of the powder, Figure 1b, shows mainly spherical particles and some larger, elongated particles. Fine satellites are visible on the particle's surfaces. The powder showed good spreadability during additive manufacturing.

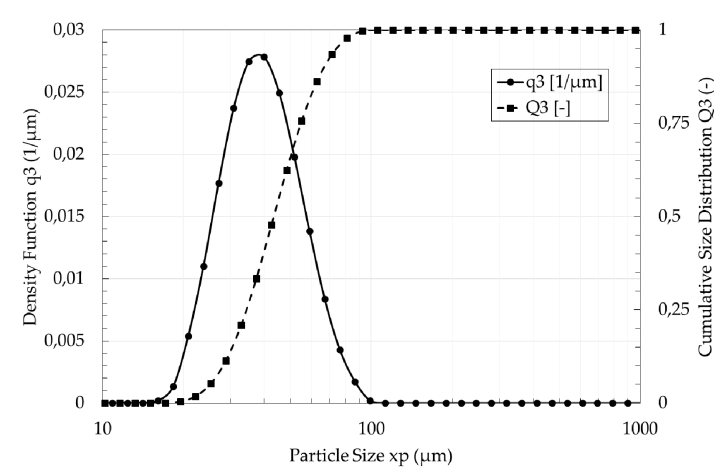

(a)

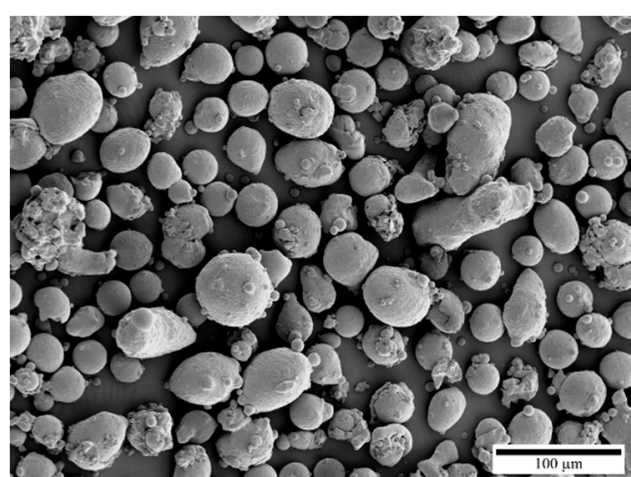

(b)

Figure 1. (a) The density function $\mathrm{q} 3$ and cumulative size distribution $\mathrm{Q} 3$ of the aluminum powder measured by laser diffraction spectroscopy. (b) SEM image of the powder particles.

\subsection{Microstructure}

The microstructure of the transverse section in the as-built condition shows the characteristic structure of the samples produced by laser powder bed fusion (Figure 2a), where the individual layers can also be seen. The size of the melt pools varied depending on the intersection angle of the viewing plane, as the scanning vectors in each layer were rotated. The boundaries of the single melt pools appeared brighter in the etched micro section. Single, fine pores can be seen distributed over the image.

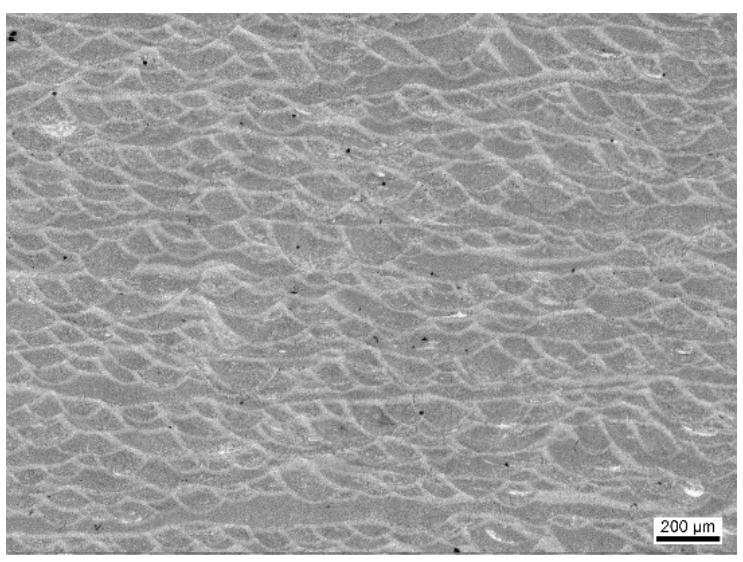

(a)

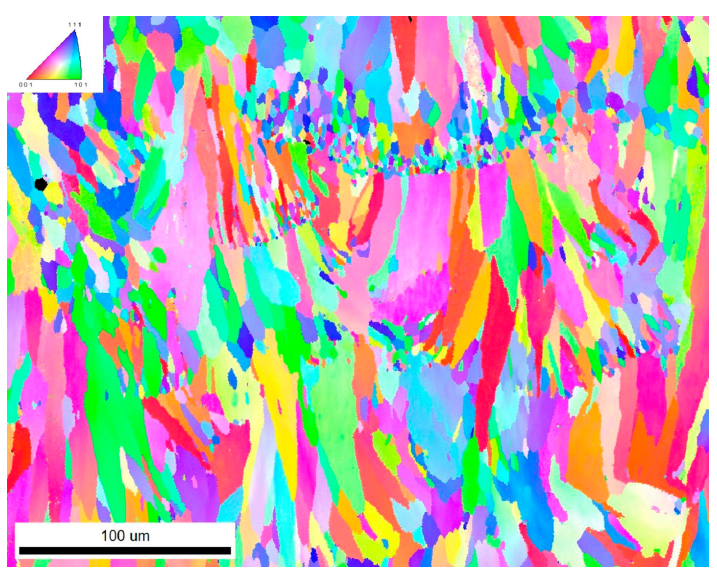

(b)

Figure 2. (a) Longitudinal micro section after etching (OM). (b) Crystal orientation map of the longitudinal micro section measured by electron backscatter diffraction (EBSD).

As in the optical microscope image, the EBSD image also shows several melt pools (Figure 2b). The lower boundary of the melt pool consisted of small equiaxed grains, whereas the rest of the melt pool consisted of larger elongated grains that extended over the height of the melt pool along the solidification direction. In the transverse direction, mainly equiaxed grains were present (Figure 3a). This confirms that the elongated grains in the longitudinal section had a columnar shape. The grain 
size also decreased in this section from the inside of the melt track towards the edge. The preferred crystal orientation was not apparent from the EBSD images.

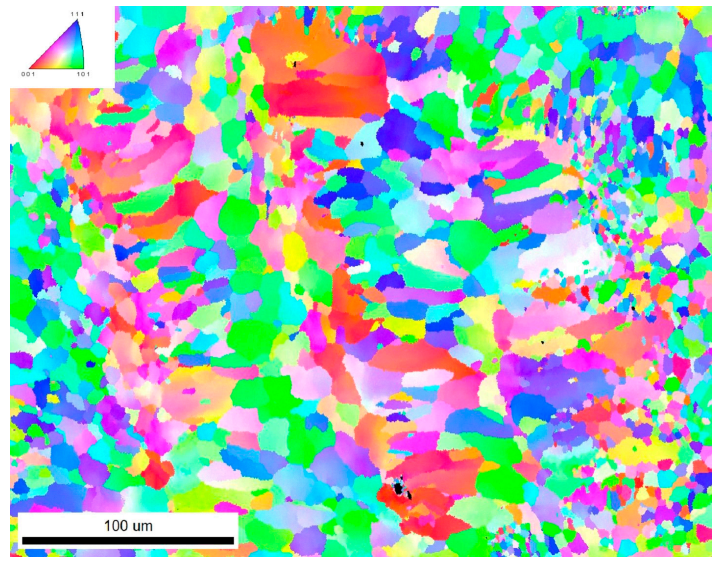

(a)

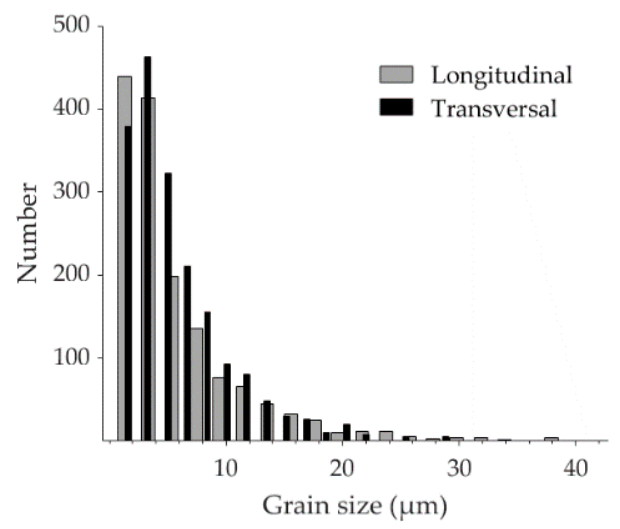

(b)

Figure 3. (a) Crystal orientation map of the longitudinal microsection measured by EBSD. (b) Grain size distribution measured by EBSD in the longitudinal and transversal direction.

Determination of the grain size distribution by EBSD revealed an average grain size of $6.2 \pm 5.7 \mu \mathrm{m}$ in the longitudinal direction and an average grain size of $6.0 \pm 4.6 \mu \mathrm{m}$ in the transverse direction (Figure 3b). Looking at the size distribution in both directions, there was a larger number of grains with a diameter of 4 to $10 \mu \mathrm{m}$ in the transverse direction but more grains smaller than $2 \mu \mathrm{m}$ in the longitudinal direction. These small grains were located at the lower boundary of the melt tracks, which were not visible in the transverse section. The areas with varying grain sizes also explain the high standard deviation of the average grain sizes of $5.7 \mu \mathrm{m}$ and $4.6 \mu \mathrm{m}$. Large elongated grains were also not visible in the transverse section, as the columnar grains formed along the solidification direction, which was parallel to the build-up direction.

Examination of the microstructure by TEM offers a better resolution of the very fine structures, which are not observable by SEM and OM. Figure 4a shows a section of the microstructure transversally oriented to the build-up direction with a very fine cell structure and diameters smaller than $1 \mu \mathrm{m}$. On the cell boundaries, a film is visible (marker 1, bright) that has a high silicon content according to the EDS measurements (Figure $4 \mathrm{~b}$, position $\sim 200 \mathrm{~nm}$ ). In addition, manganese and iron can also be detected at this position. The EDS measurements on other comparable cell boundary films show similar chemical compositions. This near-eutectic silicon network is comparable to the characteristic microstructure of the alloy AlSi10Mg after the laser powder bed fusion shown in other studies [2,20,27]; however, it is less pronounced. Precipitates, as shown in position 2 in Figure 4a, are preferentially found at the triple junctions between adjacent cells in the investigated structure. These are $\mathrm{Mg} / \mathrm{Si}$ precipitates (Figure 4 b, position $\sim 600 \mathrm{~nm}$ ). Similar chemical compositions were also detected at different points in the structures of these characteristic precipitates. Due to their high cooling rates, these particles were not primary precipitates. It is assumed that these large $\mathrm{Mg} / \mathrm{Si}$-particles were precipitated during the manufacturing process due to the increased temperature of the build platform. The STEM image in Figure $4 \mathrm{~b}$ shows the position of the EDS-line scan (orange line). The area inside the yellow rectangle was used for drift correction during the line scan. The position marked with 3 in Figure 4a is a pore that likely formed during solidification. $\mathrm{Zr}$ could not be detected in the examined area of the sample using EDS. 


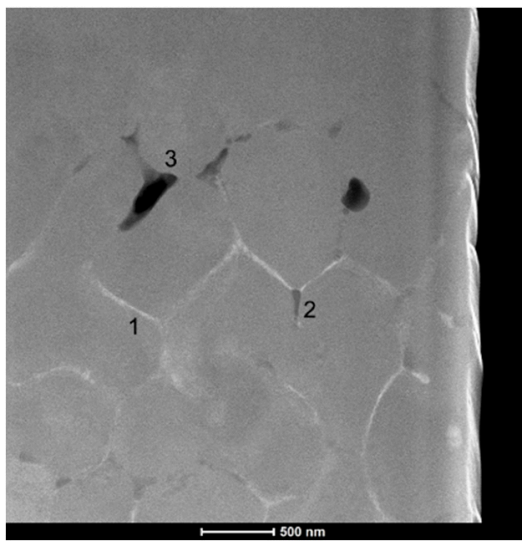

(a)
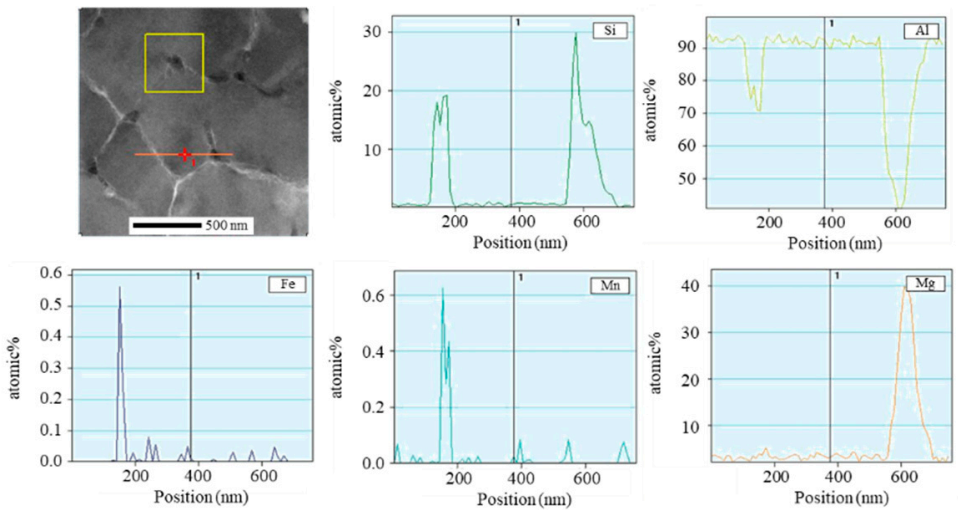

(b)

Figure 4. (a) Scanning-TEM image of microstructure transversal to the build-up direction. (b) Energy-dispersive X-ray spectroscopy (EDS)-line scan covering the core region of a cell, a cell boundary with Si-containing film and a cell boundary precipitate.

\subsection{Mechanical Properties in the As-Built and Heat Treated Material States}

Heat treatment is an important parameter for adjusting the performance of the alloy. To develop a suitable heat treatment process, it is essential to determine the mechanical properties in the as-built condition before subsequent heat treatment. Figure 5a shows that, depending on the platform- and part temperature, different mechanical properties were measured in the as-built state. At a platform temperature of $100{ }^{\circ} \mathrm{C}$, a yield strength (YTS) of $381 \pm 3 \mathrm{MPa}$, an ultimate tensile strength (UTS) of $483 \pm 3 \mathrm{MPa}$, and an elongation at break (A) of $6.1 \% \pm 1.2 \%$ can be determined in the as-built state for the specimens produced via the SLM125. By reducing the platform temperature to $50{ }^{\circ} \mathrm{C}$, a YTS of $270 \pm 1 \mathrm{MPa}$, an UTS of $442 \pm 1 \mathrm{MPa}$, and an elongation at break of $12.7 \% \pm 0.8 \%$ could be reached.

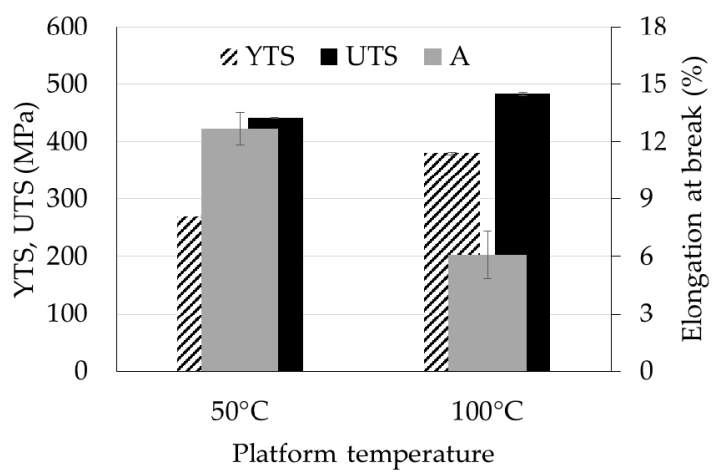

(a)

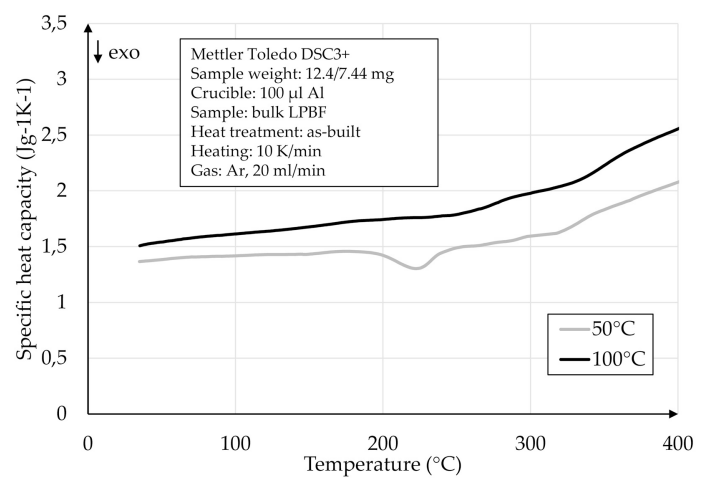

(b)

Figure 5. (a) Yield strength (YTS), ultimate tensile strength (UTS), and the elongation at break of the AlSI3.5Mg2.5 samples built at different platform temperatures. (b) Results of the differential scanning calorimetry (DSC)-measurement of the AlSI3.5Mg2.5 samples built under different platform temperatures.

An increase in strength with a simultaneous decrease in ductility with the abovementioned differences in the part's temperatures corresponds to the behavior that was expected from an in-process precipitation reaction. The DSC measurement to investigate the precipitation reactions confirmed this assumption. Comparing the two heat flow curves in Figure 5b, a difference between the two platform temperatures is observable at $230{ }^{\circ} \mathrm{C}$. The exothermic peak of the samples printed at a platform temperature of $50^{\circ} \mathrm{C}$ can be assigned to the precipitation reaction of $\beta^{\prime \prime}$ and $\beta^{\prime}$ [28]. This peak 
does not appear in the sample built up at a higher platform temperature, which suggests that a precipitation reaction had already occurred during the LPBF at a $100{ }^{\circ} \mathrm{C}$ platform temperature. A YTS of $417 \pm 3 \mathrm{MPa}$, an UTS of $506 \pm 4 \mathrm{MPa}$, and an elongation at break of $10.1 \% \pm 1.3 \%$ could be achieved by the samples manufactured using the Concept Laser M2 LPBF-system. The higher elongation at break can be explained by the more extensive parameter development when using the CL M2 system. The higher strength can be explained by increased part temperatures during manufacturing, which can lead to a stronger precipitation reaction.

AlSiMg alloys are usually strengthened by artificial ageing, starting from a supersaturated solution state. For the AlSi3.5Mg2.5 alloy, the expected increase in strength and decrease in ductility were observable in the investigated parameter window by conducting direct ageing without prior solution annealing. During an ageing time of a maximum of $10 \mathrm{~h}$ there was no over ageing, which would have manifested as a decrease in strength. The different material properties changed differently by increasing the ageing duration. While the UTS hardly increased after only one hour, the YTS and the elongation at break showed larger changes up to an ageing time of $4 \mathrm{~h}$. For all measurements of the UTS and YTS, the standard deviation was smaller than $1 \mathrm{MPa}$ such that the corresponding error bars are not visible in Figure 6a.

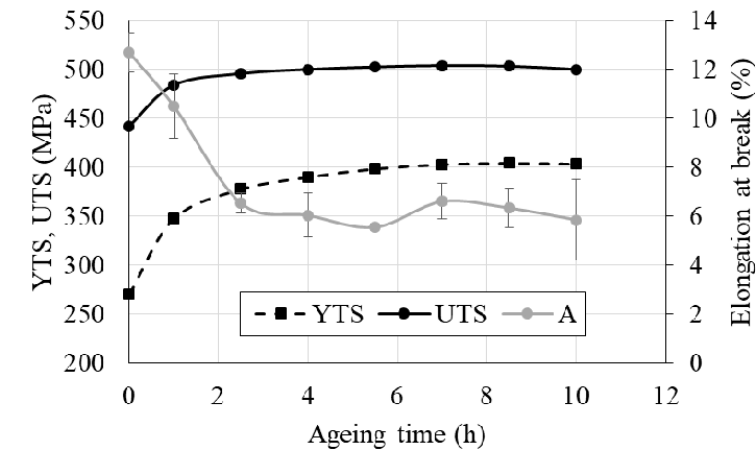

(a)

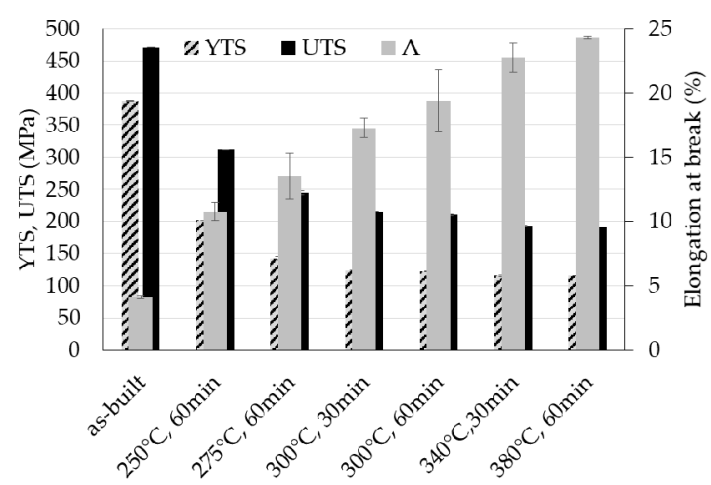

(b)

Figure 6. (a) The evolution of the mechanical properties YTS, UTS, and the elongation at break due to artificial direct ageing at $170{ }^{\circ} \mathrm{C}$. (b) Results of the soft annealing at temperatures between $250{ }^{\circ} \mathrm{C}$ and $380^{\circ} \mathrm{C}$ to establish ductile material behavior.

A well-balanced combination of strength and ductility can be achieved by artificial direct ageing for $1 \mathrm{~h}$ at $170^{\circ} \mathrm{C}$. However, Figure 6 a shows that this is the transition zone, where the ageing conditions changed quickly, and the mechanical properties stabilized with a longer ageing time. Further age-hardening experiments were carried out at $140{ }^{\circ} \mathrm{C}$ and $190{ }^{\circ} \mathrm{C}$. As shown in Table 2, the achievable UTS was only slightly dependent on the ageing temperature, whereas the YTS, elongation at break, and ageing temperature showed a strong dependency. For further characterization, ageing at $170{ }^{\circ} \mathrm{C}$ was chosen, as ageing at $140^{\circ} \mathrm{C}$ is slower and, therefore, less economical, while accelerated ageing at $190^{\circ} \mathrm{C}$ is more difficult to control.

Table 2. Selected mechanical properties after direct artificial ageing at $140{ }^{\circ} \mathrm{C}, 170{ }^{\circ} \mathrm{C}$, and $190^{\circ} \mathrm{C}$.

\begin{tabular}{ccccc}
\hline Temperature & Time & YTS (MPa) & UTS (MPa) & A (\%) \\
\hline \multirow{2}{*}{$140{ }^{\circ} \mathrm{C}$} & $1 \mathrm{~h}$ & $311 \pm 2$ & $463 \pm 4$ & $8.4 \pm 1.0$ \\
& $2.5 \mathrm{~h}$ & $323 \pm 2$ & $466 \pm 13$ & $10.2 \pm 2.0$ \\
\hline $170{ }^{\circ} \mathrm{C}$ & $1 \mathrm{~h}$ & $348 \pm 1$ & $484 \pm 1$ & $10.5 \pm 1.3$ \\
\hline \multirow{2}{*}{$190^{\circ} \mathrm{C}$} & $30 \mathrm{~min}$ & $411 \pm 1$ & $485 \pm 2$ & $4.7 \pm 0.9$ \\
& $1 \mathrm{~h}$ & $408 \pm 2$ & $475 \pm 3$ & $3.7 \pm 1.3$ \\
\hline
\end{tabular}


An increase in the ductility of the AlSi-based alloys after laser powder bed fusion is possible by soft annealing at temperatures above the artificial ageing temperature [29]. As the annealing temperature increased, the elongation at break increased, while the YTS and UTS decreased (Figure 6b). The same effect was also achieved by increasing the annealing time, as shown by a comparison of the properties after soft annealing at $300{ }^{\circ} \mathrm{C}$ for $30 \mathrm{~min}$ and $1 \mathrm{~h}$. The increase in ductility was caused by dissolution of the silicon network. The same effect was observed for AlSi10Mg [20,30].

The tight radius bending test, according to VDA 238-100, facilitates assessment of the local formability and provides a further characteristic value of ductility in addition to the elongation at break determined by the tensile test.

Table 3 shows the determined bending angle and UTS of AlSi3.5Mg2.5, as well as the two reference alloys, AlSi10Mg and Scalmalloy ${ }^{\circledR}$. The comparison of AlSi3.5Mg2.5 and AlSi10Mg shows the better formability of AlSi3.5Mg2.5 in all conditions. While the difference in the as-built state or the comparable state after artificial direct ageing at $170{ }^{\circ} \mathrm{C}$ is still small, the measured bending angle after soft annealing at $380^{\circ} \mathrm{C}$ is more than twice as large than for the alloy AlSi10Mg. The difference in the bending angle is thus greater than that for the elongation at break, as the Si network, the main factor for the high strength and limited ductility of AlSi10Mg, restricts ductility under a bending load more than under a tensile load. In the case of AlSi3.5Mg2.5, this network is significantly less pronounced due to the lower silicon content. Scalmalloy ${ }^{\circledR}$ also has a high bending angle of up to $79.1^{\circ}$; however, this is less than the maximum bending angle of AlSi3.5Mg2.5 at 96.5 . The UTS achieved in this condition is significantly higher with Scalmalloy ${ }^{\circledR}$. The enhanced ductility behavior of this alloy is due to the ultra-fine-grain $\mathrm{Al}$ matrix favored by the $\mathrm{Al}_{3}(\mathrm{Sc}, \mathrm{Zr})$ precipitates [31].

Table 3. The bending angle (VDA100-238) and UTS of AlSi3.5Mg2.5, AlSi10Mg, and Scalmalloy ${ }^{\circledR}$ under as-built conditions after direct ageing and soft annealing.

\begin{tabular}{cccc}
\hline Alloy & Heat-Treatment & Bending Angle $\mathbf{(}^{\circ}$ ) & UTS (MPa) \\
\hline \multirow{2}{*}{ AlSi3.5Mg2.5 } & as-built & $26.8 \pm 0.7$ & $407 \pm 2$ \\
& $170{ }^{\circ} \mathrm{C}, 1 \mathrm{~h}$ & $21.0 \pm 1.0$ & $453 \pm 4$ \\
& $380^{\circ} \mathrm{C}, 1 \mathrm{~h}$ & $96.5 \pm 3.0$ & $181 \pm 2$ \\
\hline \multirow{2}{*}{$\mathrm{AlSi10 \textrm {Mg }}$} & as-built & $16.7 \pm 1.2$ & $429 \pm 13$ \\
& $380^{\circ} \mathrm{C}, 1 \mathrm{~h}$ & $49.7 \pm 3.7$ & $223 \pm 2$ \\
\hline \multirow{2}{*}{ Scalmalloy ${ }^{\circledR}$} & as-built & $79.1 \pm 0.9$ & $366 \pm 3$ \\
& $325^{\circ} \mathrm{C}, 4 \mathrm{~h}$ & $27.3 \pm 0.6$ & $496 \pm 5$ \\
\hline
\end{tabular}

Figure 7 allows a comparison of the developed alloy AlSi3.5Mg2.5 with classical cast and wrought alloys, as well as the frequently used LPBF aluminum alloys, AlSi10Mg and the AlMgSc alloy, Scalmalloy ${ }^{\circledR}$, with regard to the elongation at break and UTS. Essentially, the most-balanced property profiles belong to alloys in the upper right corner of the diagram. In comparison with the conventional cast and wrought alloys, AlSi3.5Mg2.5 shows a superior combination of properties. Comparable UTS values can be achieved only by high-strength wrought alloys, such as EN AW-7075, which has lower ductility and cannot be processed using LPBF. Wrought alloys with comparable ductility provide lower strength compared to AlSi3.5Mg2.5. Compared to AlSi10Mg, AlSi3.5Mg2.5 features a better combination of strength and ductility, with both the maximum UTS achieved and the maximum elongation at break being higher. Scalmalloy ${ }^{\circledR}$ features an even better combination of ductility and strength. The disadvantage of Scalmalloy ${ }^{\circledR}$ compared to AlSi10Mg and AlSi3.5Mg2.5 is its cost efficiency, as the scandium content of the alloy increases the cost of the powder material by a factor of about ten. Thus, Scalmalloy ${ }^{\circledR}$, despite its good mechanical properties, is not applicable for many applications. 


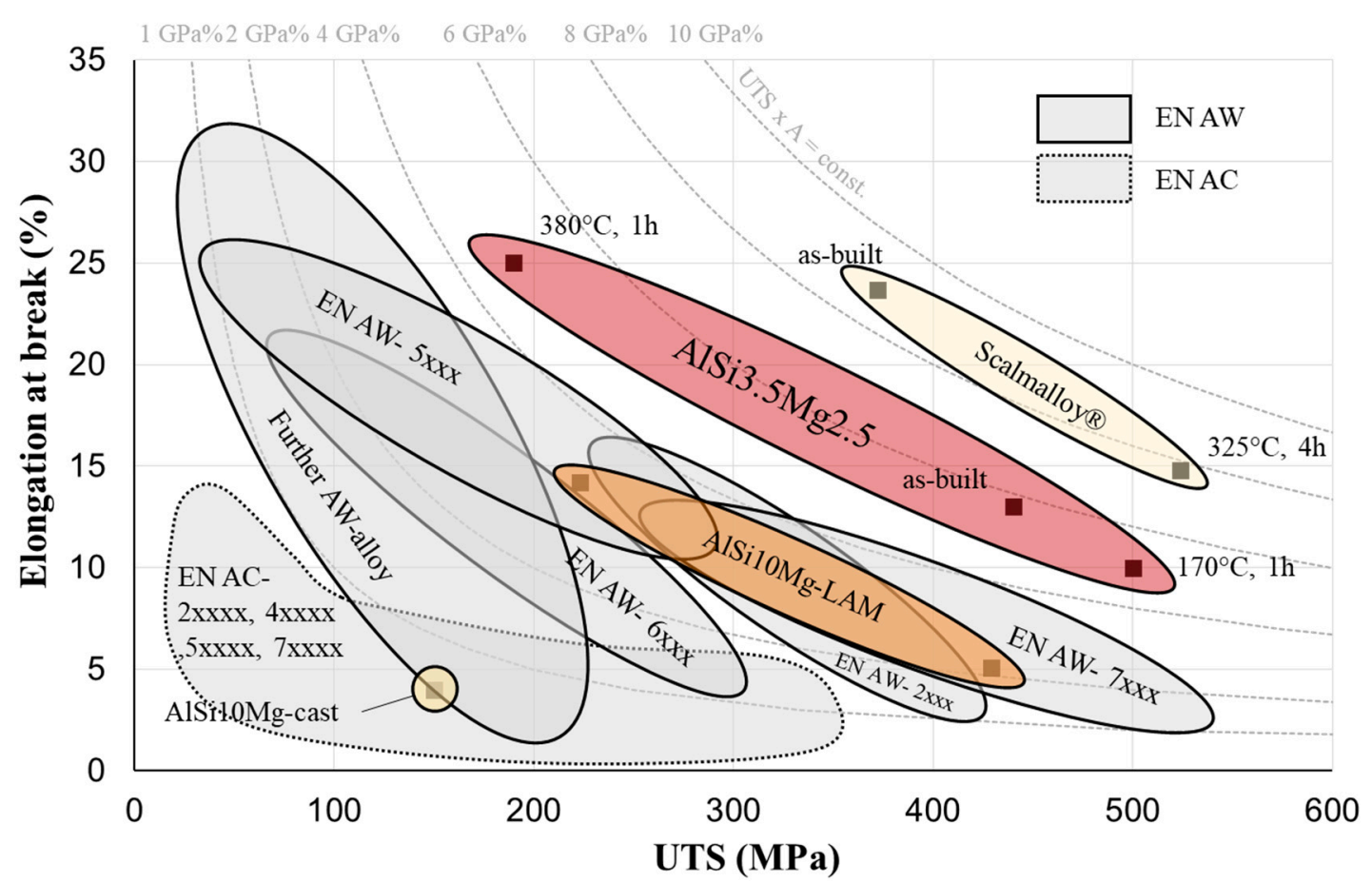

Figure 7. Comparison of the mechanical properties of elongation at break and the UTS of AlSi3.5Mg2.5 for the conventional cast and wrought alloys and for the frequently used laser powder bed fusion (LPBF) alloy AlSi10Mg, as well as the AlMgSc alloy Scalmalloy ${ }^{\circledR}$.

Compared to the other two LPBF-alloys, the mechanical properties of AlSi3.5Mg2.5 can be adjusted in a wider range through heat treatment. This results in one alloy that can cover a wide range of applications with different requirements. The absence of needing to change the material simplifies the additive manufacturing process chain, including time consuming parameter developments and the need to operate multiple LPBF-systems. Furthermore, in many industries, like automotive and aerospace, there is no more need for costly additional approval processes for different alloys. Moreover, recycling is simplified when material composites are avoided, resulting in improved resource efficiency when considering product life cycle.

For better control of the age hardening effect during the manufacturing process, a device for better cooling and control of the component temperature should be developed for future investigations. The planned studies focus on the characterization of the precipitation conditions along the build-up direction, as well as their control, prevention, and compensation.

\section{Conclusions}

The development of process-adapted alloys allows the potential of additive manufacturing to be accessible to a wider field of applications. The main results found were as follows.

1. By optimizing the silicon and magnesium content, it was possible to develop a cost-effective, high-strength Al-Si-Mg aluminum alloy for additive manufacturing without the addition of expensive alloying elements or process steps, which is particularly suitable for use in cost-sensitive fields, such as the automotive industry.

2. Laser powder bed fusion enables strong supersaturation of the aluminum solid solution in AlSiMg alloys due to its process-inherent high solidification rates. The subsequent precipitation reaction allowed us to realize a high ultimate tensile strength of $506 \pm 4 \mathrm{MPa}$, which was well above the strength of EN AW-6xxx wrought alloys. 
3. The resulting microstructure after laser powder bed fusion can vary widely by direct ageing and soft annealing of no more than $1 \mathrm{~h}$. The mechanical properties were changed significantly, so components made of the presented alloy can be used for applications requiring high strength properties as well as for applications requiring high ductility with crack-free deformation behavior. After direct ageing, the samples exhibited a UTS of $484 \pm 1 \mathrm{MPa}$, a YTS of $348 \pm 1 \mathrm{MPa}$, and an elongation at break of $10.5 \% \pm 1.3 \%$. After soft annealing, they exhibited a UTS of $179 \pm 2 \mathrm{MPa}$, a YTS of $96 \pm 6 \mathrm{MPa}$, and an elongation at break of $25.6 \% \pm 0.9 \%$.

4. Reduced silicon content enabled better ductility and formability compared to AlSi10Mg due to a less pronounced grain boundary silicon network. The resulting loss of strength could be compensated by particle strengthening with $\mathrm{Mg} / \mathrm{Si}$ precipitates.

5. The use of age-hardenable aluminum alloys in laser powder bed fusion requires more precise control of the platform or component temperatures. Otherwise, uncontrolled age-hardening may occur during the build job, which may also result in a graded mechanical property profile along the build-up direction.

\section{Patents}

A portion of the content presented has been applied as a patent at the German Patent and Trademark Office.

Author Contributions: Conceptualization, D.K. and A.v.H.; methodology, D.K. and A.L.; validation, D.K. and A.L.; investigation, D.K., A.L., and B.M.; resources, A.v.H. and B.M.; writing-Original Draft Preparation, D.K.; writing-review and editing, A.L., B.M., and A.v.H.; visualization, D.K.; supervision, A.v.H. and B.M.; project administration, D.K. and A.L.; funding acquisition, A.v.H. and B.M. All authors have read and agreed to the published version of the manuscript.

Funding: This research was funded by the German Federal Ministry of Education and Research (BMBF) within the program "Innovations for tomorrow's production, services and work", grant number 03XP0101G". The authors are responsible for the contents of this publication.

Acknowledgments: The authors thank Concept Laser GmbH, Lichtenfels, Germany, and the Fraunhofer Research Institution for Additive Manufacturing Technologies IAPT, Hamburg, Germany, for the production and provision of the sample material printed on CL M2 LPBF-systems.

Conflicts of Interest: The authors declare no conflict of interest. The funders had no role in the design of the study; in the collection, analyses, or interpretation of data; in the writing of the manuscript, or in the decision to publish the results.

\section{References}

1. Li, W.; Li, S.; Liu, J.; Zhang, A.; Zhou, Y.; Wei, Q.; Yan, C.; Shi, Y. Effect of heat treatment on AlSi10Mg alloy fabricated by selective laser melting: Microstructure evolution, mechanical properties and fracture mechanism. Mater. Sci. Eng. A 2016, 663, 116-125. [CrossRef]

2. Takata, N.; Liu, M.; Kodaira, H.; Suzuki, A.; Kobashi, M. Anomalous strengthening by supersaturated solid solutions of selectively laser melted Al-Si-based alloys. Addit. Manuf. 2020, 33, 101152. [CrossRef]

3. Tradowsky, U.; White, J.; Ward, R.M.; Read, N.; Reimers, W.; Attalah, M.M. Selective laser melting of AlSi10Mg: Influence of post-processing on the microstructural and tensile properties development. Mater. Des. 2016, 105, 212-222. [CrossRef]

4. Hesse, W. Aluminium Material Data Sheets, 7th ed.; DIN Deutsches Institut für Normung e.V.: Berlin, Germany, 2016; pp. 271-273.

5. Fiocchi, J.; Biffi, C.A.; Tuissi, A. Selective laser melting of high-strength primary AlSi9Cu3 alloy: Processability, microstructure, and mechanical properties. Mater. Des. 2020, 191, 108581. [CrossRef]

6. Pozdniakov, A.V.; Churyumov, A.Y.; Loginova, I.S.; Daubarayte, D.K.; Ryabov, D.K.; Korolev, V.A. Microstructure and properties of novel AlSi11CuMn alloy manufactured by selective laser melting. Mater. Lett. 2018, 225, 33-36. [CrossRef]

7. Fousova, M.; Dvorsky, D.; Vronka, M.; Vojtech, D.; Lejcek, P. The Use of Selective Laser Melting to Increase the Performance of AlSi9Cu3Fe Alloy. Materials 2018, 11, 1918. [CrossRef] 
8. Koutny, D.; Palousek, D.; Pantelejev, L.; Hoeller, C.; Pichler, R.; Tesicky, L.; Kaiser, J. Influence of Scanning Strategies on Processing of Aluminium Alloy EN AW 2618 Using Selective Laser Melting. Materials 2018, 11, 298. [CrossRef]

9. Karg, M.C.H.; Ahuja, B.; Wiesenmayer, S.; Kuryntsev, S.V.; Schmidt, M. Effects of Process Conditions on the Mechanical Behavior of Aluminium Wrought Alloy EN AW-2219 (AlCu6Mn) Additively Manufactured by Laser Beam Melting in Powder Bed. Micromachines 2017, 8, 23. [CrossRef]

10. Karg, M.; Ahuja, B.; Schaub, A.; Schmidt, J.; Sachs, M.; Mahr, A.; Wiesenmayer, S.; Wigner, L.; Wirth, K.-E.; Peukert, W.; et al. Effect of process conditions on mechanical behavior of aluminium wrought alloy EN AW-2618 additively manufactured by Laser Beam Melting in powder bed. In Proceedings of the Lasers in Manufacturing Conference 2015, Munich, Germany, 22-25 June 2015; Wissenschaftliche Gesellschaft Lasertechnik e.V.: Erlangen, Germany, 2015.

11. Dadbakhsh, S.; Mertens, R.; Vanmeensel, K.; Vleugels, J.; Van Humbeeck, J.; Kruth, J.-P. In situ alloying and reinforcing of Al6061 during selective laser melting. Procedia CIRP 2018, 74, 39-43. [CrossRef]

12. Uddin, S.Z.; Murr, L.E.; Terrazas, C.A.; Morton, P.; Roberson, D.A.; Wicker, R.B. Processing and characterization of crack-free aluminum 6061 using high-temperature heating in laser powder bed fusion additive manufacturing. Addit. Manuf. 2018, 22, 405-415. [CrossRef]

13. Kaufmann, N.; Imran, M.; Wischeropp, T.M.; Emmelmann, C.; Siddique, S.; Walther, F. Influence of Process Parameters on the Quality of Aluminium Alloy EN AW 7075 Using Selective Laser Melting (SLM). Phys. Procedia 2016, 83, 918-926. [CrossRef]

14. Wang, P.; Li, H.C.; Prashanth, K.G.; Eckert, J.; Scudino, S. Selective laser melting of Al-Zn-Mg-Cu: Heat treatment, microstructure and mechanical properties. J. Alloys Compd. 2017, 707, 287-290. [CrossRef]

15. Reschetnik, W.; Brüggemann, J.-P.; Aydinöz, M.E.; Grydin, O.; Hoyer, K.-P.; Kullmer, G.; Richard, H.A. Fatigue crack growth behavior and mechanical properties of additively processed EN AW-7075 aluminium alloy. Procedia Struct. Integr. 2016, 2, 3040-3048. [CrossRef]

16. Spierings, A.B.; Dawson, K.; Kern, K.; Palm, F.; Wegener, K. SLM-processed Sc- and Zr- modified Al-Mg alloy: Mechanical properties and microstructural effects of heat treatment. Mater. Sci. Eng. A 2017, 701, 264-273. [CrossRef]

17. Shi, Y.; Rometsch, P.; Yang, K.; Palm, F.; Wu, X. Characterisation of a novel Sc and Zr modified Al-Mg alloy fabricated by selective laser melting. Mater. Lett. 2017, 196, 347-350. [CrossRef]

18. Churyumov, A.Y.; Pozdniakov, A.V.; Prosviryakov, A.S.; Loginova, I.S.; Daubarayte, D.K.; Ryabov, D.K.; Korolev, V.A.; Solonin, A.N.; Pavlov, M.D.; Valchuk, S.V. Microstructure and mechanical properties of a novel selective laser melted Al-Mg alloy with low Sc content. Mater. Res. Express 2019, 6, 126595. [CrossRef]

19. Martin, J.H.; Yahata, B.D.; Hundley, J.M.; Mayer, J.A.; Schaedler, T.A.; Pollock, T.M. 3D printing of high-strength aluminium alloys. Nature 2017, 549, 365-369. [CrossRef]

20. Aboulkhair, N.T.; Simonelli, M.; Parry, L.; Ashcroft, I.; Tuck, C.; Hague, R. 3D printing of Aluminium alloys: Additive Manufacturing of Aluminium alloys using selective laser melting. Prog. Mater Sci. 2019, 106, 100578. [CrossRef]

21. Zhang, J.; Song, B.; Wei, Q.; Bourell, D.; Shi, Y. A review of selective laser melting of aluminum alloys: Processing, microstructure, property and developing trends. J. Mater. Sci. Technol. 2019, 35, $270-284$. [CrossRef]

22. Edwards, G.A.; Stiller, K.; Dunlop, G.L.; Couper, M.J. The precipitation sequence in Al-Mg-Si alloys. Acta Mater. 1998, 46, 3893-3904. [CrossRef]

23. Pakdil, M.; Çam, G.; Koçak, M.; Erim, S. Microstructural and mechanical characterization of laser beam welded AA6056 Al-alloy. Mater. Sci. Eng. A 2011, 528, 7350-7356. [CrossRef]

24. Kou, S. Welding Metallurgy, 2nd ed.; John Wiley \& Sons: Hoboken, NJ, USA, 2002; pp. 285-295.

25. Schmidtke, K.; Palm, F.; Hawkins, A.; Emmelmann, C. Process and Mechanical Properties: Applicability of a Scandium modified Al-alloy for Laser Additive Manufacturing. Phys. Procedia 2011, 12, 369-374. [CrossRef]

26. Belov, N.A.; Alabin, A.N.; Eskin, D.G.; Istomin-Kastrovskii, V.V. Optimization of hardening of Al-Zr-Sc cast alloys. J. Mater. Sci. 2006, 41, 5890-5899. [CrossRef]

27. Chen, B.; Moon, S.K.; Yao, X.; Bi, G.; Shen, J.; Umeda, J.; Kondoh, K. Strength and strain hardening of a selective laser melted AlSi10Mg alloy. Scr. Mater. 2017, 141, 45-49. [CrossRef]

28. Osten, J.; Milkereit, B.; Schick, C.; Kessler, O. Dissolution and Precipitation Behaviour during Continuous Heating of Al-Mg-Si Alloys in Wide Range of Heating Rates. Materials 2015, 8, 2830-2848. [CrossRef] 
29. Iturrioz, A.; Gil, E.; Petite, M.M.; Garciandia, F.; Mancisidor, A.M.; San Sebastian, M. Selective laser melting of AlSi10Mg alloy: Influence of heat treatment condition on mechanical properties and microstructure. Weld. World 2018, 62, 885-892. [CrossRef]

30. Maamoun, A.H.; Elbestawi, M.; Dosbaeva, G.K.; Veldhuis, S.C. Thermal post-processing of AlSi10Mg parts produced by Selective Laser Melting using recycled powder. Addit. Manuf. 2018, 21, 234-247. [CrossRef]

31. Spierings, A.B.; Dawson, K.; Heeling, T.; Uggowitzer, P.J.; Schäublin, R.; Palm, F.; Wegener, K. Microstructural features of Sc- and Zr- modified Al-Mg alloys processed by selective laser melting. Mater. Des. 2017, 115, 52-63. [CrossRef]

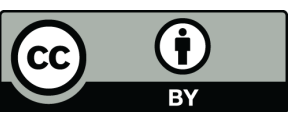

(C) 2020 by the authors. Licensee MDPI, Basel, Switzerland. This article is an open access article distributed under the terms and conditions of the Creative Commons Attribution (CC BY) license (http://creativecommons.org/licenses/by/4.0/). 